\title{
SKERSINIO PILVO RAUMENS JËGOS IR NUGAROS SKAUSMO RYŠYS NĖŠTUMO METU TAIKANT KINEZITERAPIJĄ
}

\author{
Brigita Zachovajeviené $\dot{e}^{1,2}$, Jūratė Banionyte் ${ }^{1}$, Pavelas Zachovajevas ${ }^{2,3}$, Daiva Bulotiené $\dot{e}^{3}$ \\ Kauno medicinos universitetas ${ }^{1}$, Kauno kolegija ${ }^{2}$, Lietuvos kūno kultūros akademija ${ }^{3}$, Kaunas, Lietuva
}

Brigita Zachovajevienè. Kineziterapijos magistrè. Kauno medicinos universiteto Kineziologijos ir sporto medicinos katedros doktorantė. Kauno kolegijos Reabilitacijos katedros lektorè. Mokslinių tyrimų kryptis — atramos judamojo aparato patologija néštumo metu.

\section{SANTRAUKA}

Tyrimo problema: PSO duomenimis, 25\% néščiuju skundžiasi nugaros skausmais, susijusiais su atramos judamojo aparato pokyčiais néštumo metu. Lietuvoje daug dèmesio skiriama néščiuju sveikatingumui, bet nepakankamai, ypač toms moterims, kurias vargina nugaros skausmai ar sumažèjęs mobilumas nèštumo metu.

Tyrimo objektas — néščiu moteru skersinis pilvo raumuo (SPR) ir nugaros skausmas.

Tyrimo tikslas — nustatyti ryši tarp skersinio pilvo raumens jẻgos ir nugaros skausmo néštumo metu.

Uždaviniai: 1. Ivertinti kontrolinès ir tiriamosios grupès néščiuju nugaros skausma prieš KT (kineziterapija) ir po jos. 2. Ivertinti kontrolinès ir tiriamosios grupès néščiuju skersinio pilvo raumens jèga prieš KT ir po jos. 3. Palyginti abieju grupių rezultatus prieš KT ir po jos.

Tyrimo metodika. Anketinès apklausos būdu buvo išsiaiškintas moteru amžius, nèštumo savaitè, ar šio nèštumo metu jaučia nugaros skausmus ir kada jie pasireiškia. Prieš KT ir po jos, taikant VAS (Skausmo vizualinę analogiju skale), buvo ivertintas visu tiriamuju nugaros skausmo intensyvumo suvokimas ir, naudojant liemens stabilumo vertinimo ir lavinimo prietaisq ,,Stabilizer“", atliktas objektyvus skersinio pilvo raumens jègos testavimas néščiosioms gulint ant nugaros ir šono. Taikant KT programa, tiriamosios grupès $(n=18)$ néšćiosios atliko SPR jègos stiprinimo pratimus saleje, o kontrolinès grupès $(n=16)$ — bendrojo pobūdžio pratimus vandenyje. Tyrimo duomenys statistiškai apdoroti naudojantis kompiuterine programa „SPSS 15.0 for Windows“.

Rezultatai. Tiriamojoje grupejje vidutinè nugaros skausmo intensyvumo suvokimo j̇vertinimo reikšmè po KT programos sumažejo apytiksliai $41 \%$ nuo pirmo ¿̇vertinimo gautos vidutinès reikšmès $(p<0,05)$. Tiriamosios grupés néščiuju SPR jejos vertinimo rezultatai po KT gulint ant šono apytiksliai 3,12\% (testavimo metu atitraukiant dešinę koja) ir 5,04\% (kaire koja) buvo geresni nei kontrolinés grupès ( $p<0,05)$.

Išvados: 1. Tiriamosios grupès nugaros skausmo intensyvumo suvokimas po KT sumažèjo statistiškai patikimai $(p<0,05)$, kontrolinès - išliko nepakitęs. 2. Tiriamosios ir kontrolinès grupés néščiuju skersinio pilvo raumens jèga taikant kineziterapija didèjo $(p<0,05)$. 3. Tiriamosios grupés néščiuju skausmo intensyvumo suvokimas taikant kineziterapija sumažèjo labiau nei kontrolinès $(p<0,05)$, o skersinio pilvo raumens jèga didejo labiau nei kontrolinès. 4. Skersinio pilvo raumens jèga turi įtakos nugaros skausmams nëštumo metu: didejjant liemens stabilumui, nugaros skausmas mažèja.

Raktažodžiai: skersinis pilvo raumuo, nugaros skausmas, nèštumas, kineziterapija.

\section{IVADAS}

B ent kartą gyvenime $60-80 \%$ visų žmonių yra jautę nugaros skausmą (Žuromskis, 2002). Nugaros skausmai yra didžiausia visos populiacijos sveikatos problema, o nèštumo metu jie ypač pasireiškia (Zachovajevienè, 2003). Ivairiu autorių duomenimis, skirtingose populiacijose nuo 24 iki 90\% nèščiujų vargina šis sutrikimas (Sneag, 2007). Skaičiai rodo, kad šis reiškinys gana paplitęs. Todèl daugelis, kartu ir medicinos personalas, mano, kad tai normalu ir laikui bėgant praeis (Žuromskis, 2002). Visgi daugumą moteru vargina toks intensyvus skausmas, trikdantis ne tik darbinguma, bet ir gyvenimo kokybę nëštumo metu bei po gimdymo. Dažnai atsiranda psichologinis diskomfortas dèl vaisiaus būklès, gimdymo baigties ir galimų komplikacijų néštumo metu. Patiriamas ir ekonominis nuostuolis - $30 \%$ moteru yra nedarbingos vidutiniškai apie 6 savaites (Borg-Stein et 
al., 2005). Nėštumo priežiūros specialistai daug diskutuoja apie apatinès nugaros srities skausmą nëštumo metu, ar jis yra neišvengiamas, o gal net esminis sveiko néštumo komponentas. Dalis jų mano, kad nugaros skausmas yra gyvybiškai svarbus biologinis veiksnys, atliekantis svarbiausio fiziologinio apsaugos mechanizmo vaidmeni normaliomis sąlygomis. Jis mobilizuoja visas organizmui išgyventi būtinas funkcines sistemas, padedančias nugalèti žalojamuosius veiksnius, išprovokavusius skausma, arba jų išvengti ir priverčiantis būsimą motiną būti daug atsargesnę (Gutke et al., 2008).

PSO duomenimis, 25\% nėščiujų skundžiasi nugaros skausmais, susijusiais su atramos judamojo aparato pokyčiais něštumo metu. Daugelis gydytojų, akušerių, ginekologų negali išspręsti šios problemos arba jų sprendimo būdai paprastai būna neveiksmingi. Lietuvoje daug dèmesio skiriama nėščiujų sveikatingumui, bet nepakankamai, ypač toms moterims, kurias vargina skausmai ar sumažejęs mobilumas nėštumo metu. Iškyla ir kita problema - kokie specialistai turètu gydyti nugaros skausmus nèštumo metu. Pastebèta, kad užsitęsęs skausmas něštumo metu vargina ir po gimdymo. Todèl labai svarbu ne tik nustatyti skausmo priežasti, bet pamokyti moteri taisyklingų kūno judesių ir padéčių, mažinančių skausmą (Zachovajevienè, 2006).

\section{TYRIMO METODIKA}

Tyrimo objektas: něščių moterų skersinis pilvo raumuo ir nugaros skausmas.

Tyrimo organizavimas. Tyrimui pasirinktos néščios moterys, lankančios KT užsièmimus Kauno P. Mažylio gimdymo namų ir VŠ L Kauno 2-os klinikinès ligoninès Fizinès medicinos ir reabilitacijos skyriuose.

Apie tyrimo tikslą ir metodus buvo informuojamos visos nuo 25 néštumo savaitès besilaukiančios moterys, aptartas savanoriškas dalyvavimas tyrime, anketos konfidencialumas bei atskiru duomenų viešinimas. Tyrimas pradètas gavus Bioetikos komiteto leidimą ir raštišką nėščiuju sutikimą. Visos moterys atsake i anketoje pateiktus klausimus ir joms buvo atliekamas užpakalinio dubens skausmo provokacinis mėginys norint išsiaiškinti, ar tiriamos tik juosmens skausmus jaučiančios néščiosios, atmetant bet kurią kitą skausmo priežastį. Buvo apklaustos 52 moterys, iš kurių i tiriamujų imtị nepateko 13 (4 atsisake būti tiriamos dèl asmeninių priežasčių, 4 neatitiko po anketinès apklausos tyrimo kriterijų ir 5 nèš- čiujų užpakalinio dubens skausmo provokacinis mèginys buvo teigiamas). Likusios 39 moterys tapo tiriamosiomis ir jos pačios pagal galimybę pasirinko kineziterpiją salejje ar vandenyje. Visos tiriamosios suskirstytos i dvi panašaus dydžio grupes $(\mathrm{n}=20, \mathrm{n}=19)$.

Kineziterapijos procedūros vyko 2 kartus per savaitę po 45 minutes. Pirmo ir antro testavimo metu buvo vertinamas nugaros skausmo intensyvumas naudojant skausmo pojūčio suvokimo skalę VAS, o liemens stabilumas - aparatu „STABILIZER“. Kiekviena tiriamoji antrą kartą buvo vertinama po 10 savaičių. Tyrimas truko penkis mènesius.

Po II testavimo tiriamujų imtis sumažèjo abiejose grupèse. Dvi tiriamosios grupès nėščiosios netęse KT procedūrų dèl asmeniniu priežaščių, trys kontrolinès grupès néščiosios negalèjo atsigulti ant nugaros dèl apatinès tuščiosios venos užspaudimo sindromo. Likusios $(\mathrm{n}=18, \mathrm{n}=16)$ sèkmingai buvo tiriamos antrąkart, ir gauti rezultatai analizuojami matematinès statistikos metodais. Visų tiriamujų amžiaus vidurkis $28,1 \pm 2,9$ metai, nėštumo savaičių vidutinè trukmè $26,4 \pm 1,4$.

Tiriamosios grupès nėščiosioms buvo taikyta kineziterapija salejje - jos atliko skersinio pilvo raumens stiprinimo ir bendrojo pobūdžio raumenų tempimo bei stiprinimo pratimus. Kontrolinès grupès tiriamosioms bendrojo pobūdžio raumenu tempimo, stiprinimo ir atsipalaidavimo pratimus atliko baseine.

Užpakalinio dubens skausmo provokacinis mėginys. Testo atlikimas: moteris guli ant nugaros, koja per klubo ir kelio sąnarius sulenkta $90^{\circ}$ kampu. Kineziterapeutas viena ranka fiksuoja priešingos pusès viršutini priekini klubo dyglị, kitą deda ant sulenkto kelio ir lengvai paspaudžia šlaunikaulio ašies kryptimi. Taip nustatoma, ar jaučiamas vienos pusès skausmas užpakalinèje dubens srityje (Žuromskis, 2002).

Nugaros skausmo intensyvumo vertinimas (VAS). Skausmas buvo vertinamas balais nuo 0 iki 10: 0 balu — skausmo nèra arba jis nejaučiamas; 1-3 balai - jaučiamas silpnas skausmas, kuris išnyksta pakeitus padèti; 4 -5 balai - jaučiamas nestiprus skausmas; $6-7$ balai - jaučiamas pakenčiamas nuolatinis skausmas, kuris stiprejja judant, bet pacientė gali atlikti daugeli judesių iki galo; 8-9 balai — jaučiamas stiprus skausmas, dèl kurio pacientè negali susikoncentruoti ir atlikti paprastų judesių; 10 balu — jaučiamas pats didžiausias, nepakeliamas skausmas. Tiriamuju buvo paprašoma pirštu parodyti labiausiai skaudamą vietą ir vertinti tos vietos skausmą nuo 0 iki 


\begin{tabular}{|c|c|c|}
\hline SPR jègos reikšmès, mmHg & Rangas & SPR jègos reikšmės, mmHg \\
\hline-2 & 0 & 2 \\
\hline$[-14 ; 3]$ & 1 & {$[3 ; 14]$} \\
\hline$[-27 ;-15]$ & 2 & {$[15 ; 27]$} \\
\hline$[-28 ;-40]$ & 3 & {$[28 ; 40]$} \\
\hline
\end{tabular}

Lentelè. Suranguotos SPR jègos įvertinimo reikšmès
10. Tiriamosios skausmo vietą VAS skalès tiesèje žymèjo pačios.

Liemens stabilumo vertinimas. Objektyvi skersinio pilvo raumens (SPR) jèga buvo vertinama „Stabilizer” aparatu („Chattanooga group“, USA). Tiriamuju buvo prašoma atlikti lètus koju kèlimo judesius, prieš tai sutraukus SPR ir stabilizavus liemeni. Tiriamosios gulejo ant plokščio lygaus paviršiaus. SPR funkcijai vertinti buvo taikomos dvi padetys. Viena - gulint ant nugaros (kojos per kelius sulenktos, pėdos remiasi i pagrinda, ant kurio guli). Prietaiso pagalvèlè padèta po juosmenine stuburo dalimi. Tiriamoji iškvèpdama, atlikdama lètus judesius viena koja, ir, sutraukusi SPR, turèjo stengtis išlaikyti kuo stabilesnę juosmeninę stuburo dali. Per 5 sekundes šlaunis lenkiama sulenkus blauzdą ir per 5 sekundes nuleidžiama i pradinę padètị. Ta pati tiriamoji turejjo pakartoti kita koja. Antra padètis - gulint ant šono (apatinè koja sulenkta per klubo ir kelio sąnarius, viršutinè - tiesi). Prietaiso pagalvèlè dedama tarp klubakaulio skiauterès ir šonkalių. Stabilizavus liemeni, tiriamoji buvo prašoma lètai ir tolygiai per 5 sekundes šlauni pritraukti iki pečiu aukščio ir per 5 sekundes grį̌ti i pradinę padètị.

Prieš pradedant judesi, dinamometro spaudimas nustatomas iki $40(\mathrm{mmHg})$ dydžio. Judesio metu dinamometro ekrane stebimi besikeičiantys skalès duomenys. Spaudimo sumažejjimo ar padidejjimo skirtumas yra fiksuojamas, ir registruojamas dviejų testavimo vertinimų vidurkis. Prietaiso vertinimo tikslumas $\pm 3 \mathrm{mmHg}$, svoris $600 \mathrm{~g}$.

Liemens stabilumo vertinimo duomenys turejjo teigiamu ir neigiamų reikšmių, kurių dydis kito priklausomai nuo spaudimo stiprumo i prietaiso pagalvèlę. Jei spaudimas i ją padidėdavo, tai dinamometro rodyklè pakildavo ị viršų, ir buvo gautos teigiamos reikšmès, jei sumažèdavo - neigiamos. Taigi stebint dinamometro rodyklès pokyčius galima sužinoti, ar juosmuo yra stabilus judesiu metu (rodyklè išlieka vietoje arba šiek tiek juda), padidèja ar sumažèja juosmens lordozè ir šoninis lenkimas. SPR jëgą ir funkciją stabilizuojant juosmeninę stuburo sriti, parodo dinamometro rodyklès pokytis. Jei tas skirtumas mažas, rodo gerą SPR aktyvuma, jei pokytis ryškus - galima ịtarti SPR silpnumą ir sutrikusią liemens stabilumo funkciją.

Kadangi SPR vertinimo duomenys turejo teigiamų ir neigiamų reikšmių, tai jos buvo suranguotos i 4 intervalus, kuriu kievienas turèjo po vieną reikšmę (žr. lent.). Neranguojant rezultatų teigiamų ir neigiamų reikšmių suma būtų lygi 0 ir iškreiptu realius tyrimo rezultatus.

Statistinè analizè. Statistinė duomenų analizè atlikta naudojant SPSS for Windows 15.0 programą. Kiekybiniai kintamieji pateikiami kaip aritmetinis vidurkis $(\mathrm{m})$ ir standartinè vidurkio įverčio paklaida (SEM). Kokybiniai kintamieji pateikiami procentais.

Nepriklausomų imčių kintamujų palyginimui naudotas neparametrinis Manio Vitnio (Man-Witney) ir Vilkoksono (Wilcoxon) testas $\left(Z_{M}\right)$, priklausomų imčių - neparametrinis Vilkoksono testas $\left(Z_{V}\right)$.

Neparametriniai testai pasirinkti dèl to, kad kintamujų imtys nedidelès $(\mathrm{n}=18, \mathrm{n}=16)$. Liemens stabilumo vertinimo duomenys buvo suskirstyti i skales pagal pasirinktus intervalus, nes buvo teigiamų ir neigiamų rezultatų reikšmių, ir jų skaičiaus vidurkis neatskleistų realių rezultatų. Tikrinant statistines hipotezes, buvo pasirinktas 0,05 reikšmingumo lygmuo.

\section{REZULTATAI}

Palyginus gautus rezultatus prieš KT ir po jos, tiriamosios grupès viduje (1 pav.) matyti, kad vidutinè nugaros skausmo intensyvumo suvokimo ivertinimo reikšmė po KT programos sumažèjo apytiksliai 1,39 balo, t. y. $41 \%$ nuo pirmo ivvertinimo gautos vidutinès reikšmès. Šis pokytis buvo statistiškai reikšmingas $(\mathrm{p}<0,05)$.

Palyginus gautus rezultatus prieš KT ir po jos tarp kontrolinės grupès tiriamuju (1 pav.), galima teigti, kad nugaros skausmo intensyvumo įvertinimo reikšmè po KT programos apytiksliai padidejo 0,07 (VAS) balais, ir tai sudarè 2,07\% pirmo ivertinimo gautos vidutinès reikšmès. Statistiškai patikimo skirtumo tarp skausmo intensyvumo suvokimo vertinimo prieš $\mathrm{KT}$ ir po jos kontrolineje grupeje nepastebèta. 
1 pav. Nugaros skausmo intensyvumo suvokimo vertinimo rezultatai

2 pav. Tiriamosios grupès liemens stabilumo vertinimo rezultatai

3 pav. Kontrolinès grupės liemens stabilumo vertinimo rezultatai
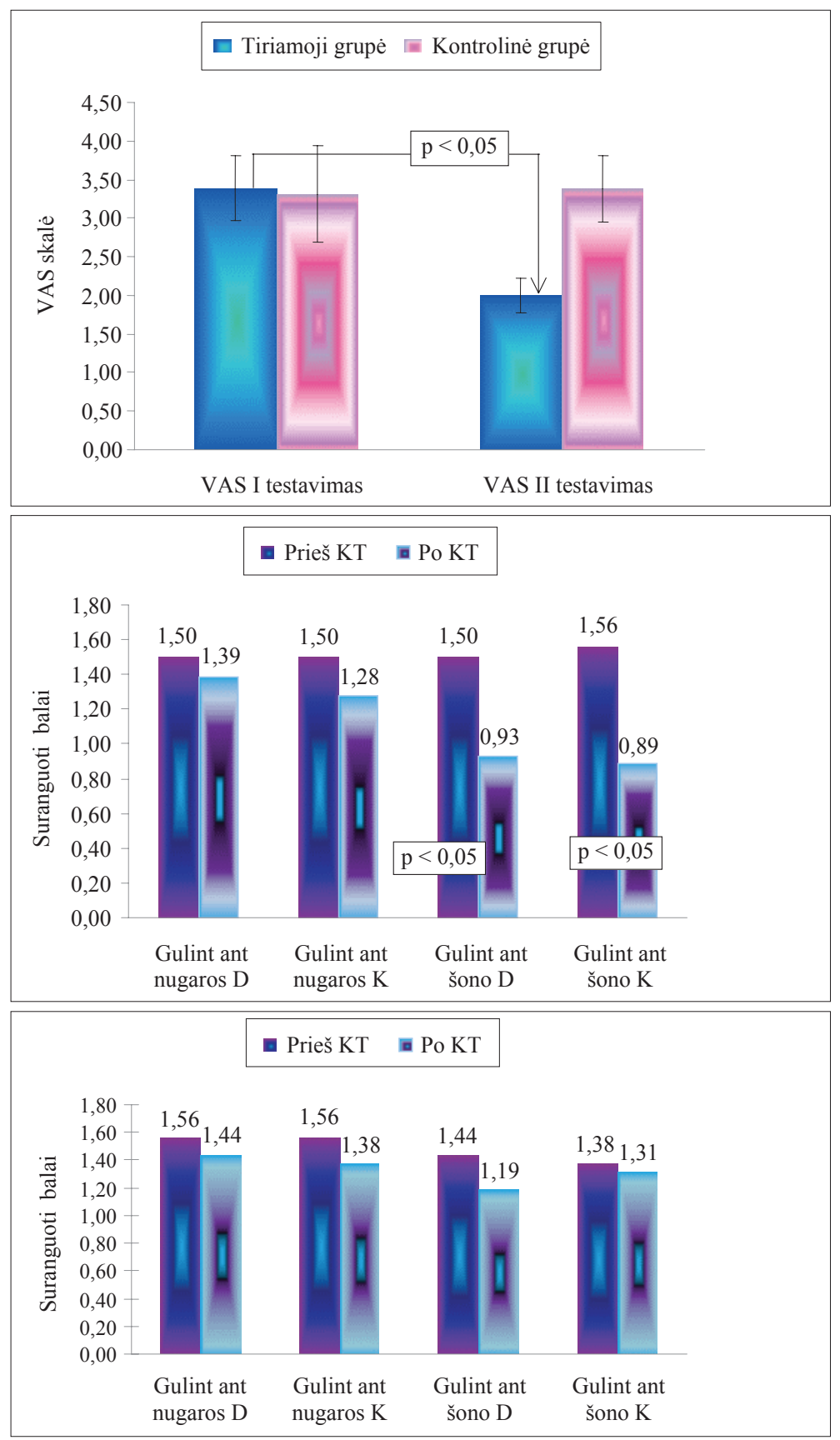

Kontrolinès grupès tiriamujų nugaros skausmo intensyvumas po KT nesumažejo, o vidutinè ivvertinimo reikšmè šiek tiek padidèjo $(2,07 \%)$. Šiuos rezultatus galima paaiškinti taip: per KT procedūras vandenyje nebuvo akcentuojamas SPR jègos didinimas, o atliekami tik bendrojo pobūdžio raumenų stiprinimo pratimai baseine taikant tempimo ir atsipalaidavimo elementus.

Apibendrinus kontrolinès grupès rezultatus skausmo požiūriu nustatyta: nugaros skausmo intensyvumas nepadidejo, nes progresuojant nèštumui didejanti gimda dar labiau tempia SPR ir silpneja liemens stabilumo palaikymo funkcija.

Rezultatu palyginimas buvo atliekamas rangais. Lyginant tiriamosios grupès SPR jègos vertini- mo rezultatus gulint ant nugaros prieš KT ir po jos (2 pav.), galima matyti, kad vidutinè suranguotu rezultatų reikšmė keliant dešinę koją sumažèjo 0,11 rango, t. y. $\Delta 1,32 \mathrm{mmHg}$ (pokytis $1,32 \%$ mažesnis). Keliant kairę koją, vidutinè suranguotų rezultatų reikšmè sumažèjo 0,22 rango, t. y. $\Delta 2,64 \mathrm{mmHg}$ (pokytis 2,64\% mažesnis). Rangui mažèjant, SPR jèga dideja. Statistiškai patikimo skirtumo prieš KT ir po jos tarp SPR jègos vertinimo gulint ant nugaros tiriamojoje grupeje nebuvo.

Tiriamosios grupès liemens stabilumo vertinimo rezultatai tiriamosioms gulint ant nugaros rodo gerą SPR jègos didèjimą po KT programos salèje (keliant dešinę koją 1,32\% pagerèjo vidutinè suran- 
guotų rezultatų reikšmė, kairę - 2,64\%). Tačiau statistiškai patikimo pagerejjimo nenustatyta.

SPR skaidulos néštumo metu labiausiai išsitempia ties baltaja pilvo linija (Zachovajeviené, 2006). Pakartotinai testuojant tiriamosios grupės moteris, kurių nèštumo savaičių vidurkis buvo $36,5 \pm 1,4$, SPR ir kiti pilvo raumenys buvo labiau ištempti, nei vertinant pirmą kartą. Tiriamosioms gulint ant nugaros, vertinimo rezultatai daugiausia priklausè nuo šios SPR dalies aktyvumo. Tai paaiškina tiriamosios grupés SPR jègos menko didejjimo rezultatus.

Lyginant tiriamosios grupès SPR jègos vertinimo rezultatus, tiriamosioms gulint ant šono, prieš KT ir po jos (2 pav.) matyti, kad vidutiné suranguotu rezultatu vertinimo reikšmè atitraukiant dešinę koją sumažejo 0,57 rango, t. y. $\Delta 6,84 \mathrm{mmHg}$ (pokytis 6,84\% mažesnis). Atitraukiant kairę koja, vidutinè suranguotų rezultatu vertinimo reikšmė sumažèjo 0,67 rango, t. y. $\Delta 8,04 \mathrm{mmHg}$ (pokytis $8,04 \%$ mažesnis). Tiriamosios grupès SPR jèga, nėščiosioms gulint ant šono, po tyrimo statistiškai reikšmingai pagerèjo $(\mathrm{p}<0,05)$.

Tokiu rezultatų buvo tiketasi, nes tiriamosios grupès něščiosioms buvo taikyta KT programa, kurios metu akcentuojamas SPR jègos stiprinimas. Tiriamosioms gulint ant šono, vertinimo rezultatai daugiausia priklausė nuo šoninių SPR dalies skaiduliu aktyvumo. Progresuojant nėštumui, SPR dalys, esančios pilvo šonuose, mažiau ištempiamos nei priekine šio raumens dalis. D. J. Critchley ir J. F. Coutts (2002) teigia, kad storiausia SPR raumens dalis yra liemens šonuose, tarp klubakauliu skiauterių bei šonkaulių ir išugdo didžiausią jègą. Tai paaiškina statistiškai patikimą SPR jègos augimą.

Lyginant kontrolinès grupès SPR jègos vertinimo rezultatus, tiriamosioms gulint ant nugaros, prieš KT ir po jos ( 3 pav.) matyti, kad vidutinè suranguotų rezultatų reikšmè keliant dešinę koją sumažejo 0,12 rango, t. y. $\Delta 1,44 \mathrm{mmHg}$ (pokytis $1,44 \%$ mažesnis). Keliant kairę koją, vidutinè suranguotu rezultatų reikšmè sumažejo 0,18 rango, t. y. $\Delta 2,16 \mathrm{mmHg}$ (pokytis $2,16 \%$ mažesnis). Rangui mažèjant, SPR jèga mažèja. Statistiškai patikimo skirtumo prieš KT ir po jos tarp SPR jègos vertinimo, tiriamosioms gulint ant nugaros, kontrolinejje grupejje nebuvo.

Liemens stabilumo vertinimo rezultatai kontrolinejje grupeje, tiriamosioms gulint ant nugaros, rodo nedideli SPR jègos pagerèjimą po KT programos vandenyje (keliant dešinę koją, 1,44\% pagerejo vidutinè suranguotu rezultatų reikšmè, o kairę $-2,16 \%$ ), bet statistiškai patikimo skirtumo nenustatyta. Pakartotinai testuojant tiriamosios grupès moteris, kurių nèštumo savaičių vidurkis buvo $36,3 \pm 1,4$, SPR ir kiti pilvo raumenys buvo labiau ištempti, nei vertinant pirmą kartą. Tokių rezultatų tikètasi, nes kontrolinèje grupeje buvo taikyta bendrojo pobūdžio makšta vandenyje, neakcentuojant SPR jëgos stiprinimo. Netaikant SPR jègos stiprinimo pratimų, liemens stabilumas mažèja dèl susilpnèjusio ir pertermpto SPR skaidulų.

\section{REZULTATŲ APTARIMAS}

Palyginus apibendrintus kontrolinès ir tiriamosios grupių rezultatus matyti, kad tyrimo pradžioje atlikus pirmą nugaros skausmo intensyvumo testavimą tiriamosios grupès něščiujų vidutinė skausmo intensyvumo suvokimo vertinimo reikšmė apytiksliai $0,8 \%$ buvo didesnè nei kontrolinès grupès, po antro - jau $13,8 \%$ mažesnè $(\mathrm{p}<0,05)$.

Atlikus lyginamają skausmo intensyvumo suvokimo rezultatu analizę tarp grupių galima teigti, kad po 10 savaičiu kontrolinès grupès tiriamuju skausmo intensyvumo suvokimas nesumažejo, bet liko apytiksliai panašus, kai tuo tarpu tiriamosios grupès skausmo intensyvumo suvokimas sumažejo $41 \%$ nuo pradinès jo reikšmès $(\mathrm{p}<0,05)$. Skausmo suvokimo skirtumas tarp grupiu po KT sudare 1,38 balo ( $p<0,05)(1$ pav.).

Gautus rezultatus paaiškina tai, kad tiriamosios grupès KT metu buvo akcentuojamas SPR jègos stiprinimas. SPR turi itakos nugaros skausmui, nes jis yra pagrindinis liemens satbilizatorius. Mūsų rezultatai sutampa su P. W. Hodges (1999) gautaisiais. Užsienio autoriai, ieškodami sąsajų tarp nugaros skausmo ir liemens stabilumo, atliko ịvarių bandymų, kurių metu buvo vertinama SPR funkcija. Vienas iš jų parodè, kad SPR funcija buvo sumažejjusi (pavèluotai raumuo susitraukdavo), kai tiriamasis, jaučiantis nugaros skausmą, atlikdavo greitą judesį koja visomis kryptimis. Tyrejai C. Liebenson (2004), C. Richardson ir kt. (2004), P. W. Hodges ir G. L. Moseley (2003) teigia, kad labai dažnai apatinès nugaros srities skausmą jaučiantys žmonès, turi giliujų (skersinių pilvo ir daugiašakių) raumenų sutrikimų, kurie funkciškai stabilizuoja liemeni. D. J. Critchley ir J. F. Coutts (2002) ivertino sveiku ir nugaros skausmą jaučiančiu tiriamuju SPR jègą. Ultragarsu buvo tiriamas SPR storio kitimas ramybès būsenoje ir susitraukimo metu. Raumens storio padidejjimas rode raumens aktyvuma. Tiriamosios grupès (sveikų tiriamujų) SPR storio pokyčių vidurkis buvo mažesnis nei kontrolinès. Vadinasi, kai jaučiamas apatinès nugaros srities skausmas, 
4 pav. Liemens stabilumo vertinimo rezultaty tarp grupių palyginimas prieš KT ir po jos, tiriamosioms gulint ant nugaros ir keliant dešinę koją
5 pav. Liemens stabilumo vertinimo rezultaty tarp grupių palyginimas prieš KT ir po jos, tiriamosioms gulint ant nugaros ir keliant kairę koją
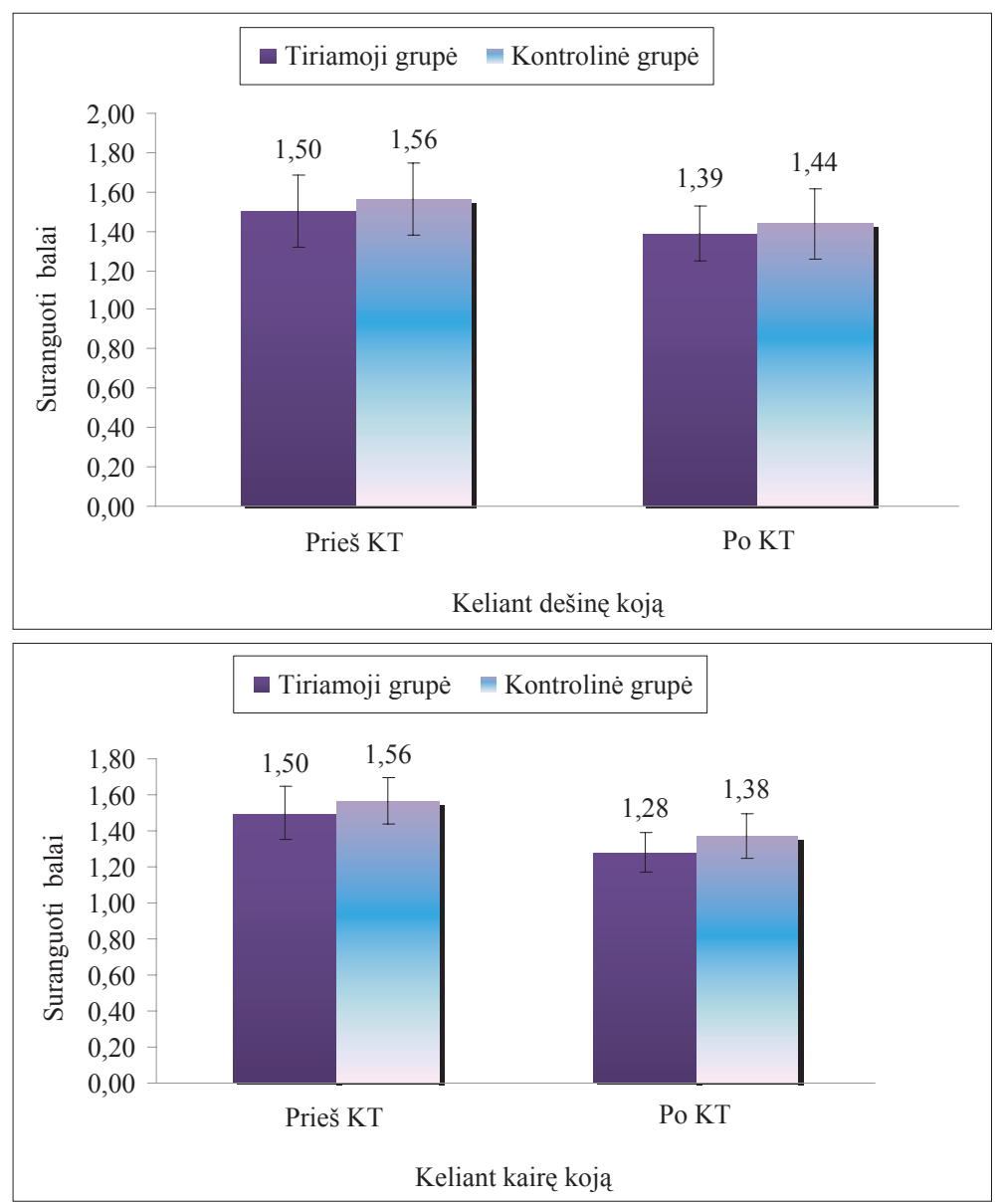

SPR jèga būna mažesnè (Richardson et al., 2004). Pagimdžiusiu moteru SPR storis buvo nedaug mažesnis nei negimdžiusių, bet šis skirtumas nebuvo statistiškai reikšmingas.

Tyrimo pradžioje, palyginus apibendrintus kontrolinès ir tiriamosios grupès rezultatus ir atlikus pirmą SPR jègos testavimą tiriamosioms gulint ant nugaros, paaiškejjo, kad tiriamosios grupès nëščiuju vidutinès suranguotų rezultatų reikšmès keliant dešinę ir kairę kojas apytiksliai $0,72 \%$ buvo mažesnès nei kontrolinès grupès. Po antro vertinimo tiriamosios grupès moteru vidutinès suranguotų rezultatu reikšmès apytiksliai $0,6 \%$ (keliant dešinę koją) ir $1,2 \%$ - (keliant kairę koją) buvo mažesnès nei kontrolinès grupès tiriamujų (4 ir 5 pav.).

Atlikus lyginamają SPR jègos ịvertinimo, tiriamosioms gulint ant nugaros, tarp grupiu analize galima teigti, kad po 10 savaičių SPR jègos augimas šiek tiek pagerejo abiejose grupèse. Nors tiriamosios grupès moteru SPR jègos vertinimo rezultatai buvo geresni, statistiškai reikšmingo skirtumo tarp tiriamu grupių po KT programos nebuvo.

Tyrimo pradžioje palyginus apibendrintus kontrolinès ir tiriamosios grupès rezultatus po pirmo SPR jègos vertinimo, tiriamosioms gulint ant šono, paaiškejjo, kad tiriamosios grupés něščiujų vidutinès suranguotu rezultatų reikšmės apytiksliai $0,72 \%$ (atitraukiant dešinę koją) ir 2,16\% (atitraukiant kairę) buvo didesnès nei kontrolinès grupès. Visgi po antro vertinimo tiriamosios grupès néščiuju vidutinės suranguotų rezultatų reikšmès apytiksliai 3,12\% (atitraukiant dešinę koją) ir 5,04\% (kairę koją) buvo mažesnès nei kontrolinès grupès tiriamuju ( $p<0,05)$. Rangui mažèjant, SPR jèga didejja (6 ir 7 pav.).

Atlikus lyginamają SPR jègos ivertinimo, tiriamosioms gulint ant šono, tarp grupių analizę galima teigti, kad po 10 savaičiu KT programos kontrolinès grupès tiriamujų SPR jèga šiek tiek pagerèjo (atitraukiant dešinę koją - 3\%, kairę - 0,84\%), tačiau liko apytiksliai vienoda. Kai tuo tarpu tiriamosios grupès nėščiujų SPR jëgos augimas 6,84\% (atitraukiant dešinę koją) ir 8,04\% (kairę koją) pagerèjo, lyginant su pradine jos reikšme $(\mathrm{p}<0,05)$.

Tiriamosios grupès statistiškai patikimą SPR jègos augimą, néščiosioms gulint ant šono, paaiškina tai, kad jų KT programos metu buvo akcentuojamas SPR jègos stiprinimas. Be to, D. J. Critchley ir J. F. Coutts (2002) teigia, kad storiausia SPR raumens dalis yra liemens šonuose, tarp klubakaulių skiauterių bei šonkaulių ir išugdo didžiausią jèga, o gulint ant šono vertinimo rezultatai daugiausia priklausè nuo šoninių SPR dalies skaiduliu aktyvumo. 

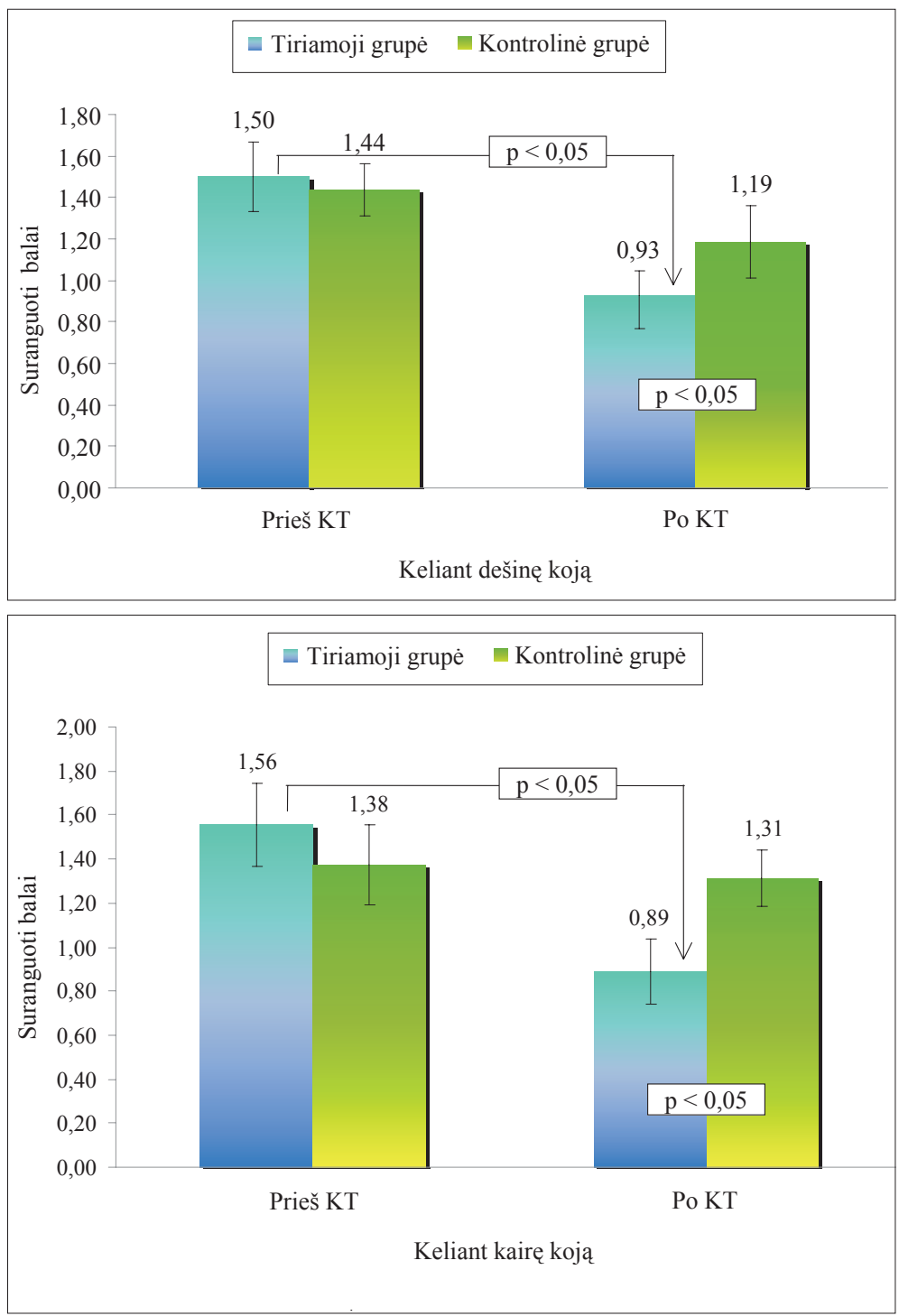

6 pav. Liemens stabilumo vertinimo rezultatų tarp grupių palyginimas prieš KT ir po jos, tiriamosioms gulint ant šono ir keliant dešinę koją
7 pav. Liemens stabilumo vertinimo rezultatų tarp grupių palyginimas prieš KT ir po jos, tiriamosioms gulint ant šono ir keliant kairę koją
C. Richardson ir kt. (2004) pastebejo, kad SPR toninès funkcijos sumažejimas yra aiškiai pastebimas tiriant apatinès nugaros srities skausmus turinčius ligonius. Néštumo metu ypač veikiami raumenys, garantuojantys dinaminį liemens stabiluma. Susilpnejus ar pertempus SPR, liemuo gali pasidaryti nestabilus ir sukelti nugaros skausmus (May, Johnson, 2008).

\section{IŠVADOS}

Tiriamosios grupès nèščiuju nugaros skausmo intensyvumo suvokimas po kineziterapijos sumažejo statistiškai patikimai $(\mathrm{p}<0,05)$. Kontrolinèje grupejje skausmo intensyvumo suvokimas išliko nepakitęs.

Tiriamosios ir kontrolinès grupių néščiuju skersinio pilvo raumens jèga taikant kineziterapija didejo $(\mathrm{p}<0,05)$.

Tiriamosios grupès néščiujų skausmo intensyvumo suvokimas taikant kineziterapiją sumažejo labiau nei kontrolinès $(\mathrm{p}<0,05)$, o skersinio pilvo raumens jègos prieaugio kaita buvo didesnè nei kontrolinès.

Skersinio pilvo raumens jèga turi itakos nugaros skausmams nëštumo metu: didejjant liemens stabilumui, nugaros skausmas mažèja.

\section{LITERATŪRA}

Borg-Stein, J., Dugan, S., Gruber, J. (2005). Musculoskeletal aspects of pregnancy. American Journal of Physical Medicine \& Rehabilitation, 84 (3), 180-192.

Critchley, D. , Coutts, J. F. (2002). Abdominal muscle function in chronic low back pain patients: Measurement with real-time ultrasound scanning. Physiotherapy, 88 (6), $322-332$.
Gutke, A., Ostgaard, C. H, Oberg, B. (2008). Predicting persistent pregnancy-related low back pain. Spine, 33 (12), 386-393.

Hodges, P. W. (1999). Is there a role for transversus abdominis in lumbo-pelvic stability? Manual Therapy, 4 (2), $74-86$. 
Hodges, P. W, Moseley, G. L. (2003). Pain and motor control of the lumbopelvic region: Effect and possible mechanisms. Journal of Electromyography and Kinesiology, 13, 361-370.

Liebenson, C. (2004). Spinal stabilization-an update. Part 2-functional assessment. Journal of Bodywork and Movement Therapies, 8, 199-210.

May, S., Johnson, R. (2008). Stabilisation exercises for low back pain: A systematic review. Physiotherapy, 94, $179-189$.

Richardson, C., Snijders, C. J., Hides, J. et al. (2004).

The relation between the transversus abdominis muscles, sacroiliac joint mechanics, and low back pain. Exercise Physiology and Physical Examination, 27 (2), 399- 405.

Sneag, B. D., Bendo, J. A. (2007). Pregnancy-related low back pain. Orthopedics, 30 (10), 839-845.

Zachovajevienè, B. (2006). Atramos judamojo aparato pokyčiai ir stuburo skausmai néštumo metu. Kineziterapija, 1 (7), 15-19.

Zachovajevienè, B. (2003). Dubens raiščių atsipalaidavimo sindromas nèštumo metu. Kineziterapija, 1 (4), 34-36.

Žuromskis, T. (2002). Nèštumas ir nugaros skausmas. Lietuvos akušerija ir ginekologija, T. V, 3, 220-223.

\title{
RELATIONSHIP BETWEEN TRANSVERSUS ABDOMINIS MUSCLE AND BACK PAIN DURING PREGNANCY IN PHYSIOTHERAPY TREATMENT
}

\author{
Brigita Zachovajevienè ${ }^{1,2}$, Jūratė Banionyte் ${ }^{1}$, Pavelas Zachovajevass ${ }^{2,3}$, Daiva Bulotiené $\dot{e}^{3}$ \\ Kaunas University of Medicine ${ }^{1}$, Kaunas College ${ }^{2}$, Lithuanian Academy of Physical Education ${ }^{3}$, \\ Kaunas, Lithuania
}

\begin{abstract}
Problem of research: World health orgaization informs, that $25 \%$ of pregnant women complain about pains during their pregnancies. Prenatal care is given much attention but not enough for back pain treatment in Lithuania.

The object of research: Strength of transversus abdominis muscle and back pain in pregnant women. The aim of research: find the relationship between transversus abdominis muscle and back pain during pregnancy. Goals of research: 1. Evaluate the back pain in control and training groups before and after the physiotherapy. 2. Evaluate the strength of transversus abdominis muscle in control and training groups before and after the physiotherapy. 3. Compare the results between control and training groups. Methods of research: With the help of a questionnaire we determined the subjects' age, gestational week, presense of back pain during the current pregnancy and its occurance. The back pain was evaluated for all women using VAS before and after the physiotherapy. Transversus abdominis muscle strength for all the paricipans was objectively tested lying on the back and side, using trainer of the transversus abdominis muscle and function measurement device "Stabilizer". The physiotherapy program for the training group (18) was focusing on transversus abdominis strengthening in the gym hall, and the control group participants (16) were performing general physiotherapy exercises program in the water. The data of the study were analyzed using SPSS 15.0 for Windows.

Results: The mean value of back pain intensity in the training group decreased by $41 \%$ compared to the primary results after physiotherapy, $(\mathrm{p}<0.05)$. Assessment outcomes of transversus abdominis strength, lying on the side and performing the measurements with the right leg were better by $3.12 \%$ and left $-5.04 \%$, in the training group than in the control group after the physiotherapy program, $(\mathrm{p}<0.05)$.

Conclusions: 1) The back pain decreased statistically significantly in the training group participants after the physiotherapy program $(\mathrm{p}<0.05)$, and it remained unchanged in the control group participants. 2) The strength of transversus abdominis muscle increased in both groups after the physiotherapy $(\mathrm{p}<0.05)$. 3) The intensity of the back pain decreased more in the training group than in the control group during the physiotherapy program, $(\mathrm{p}<0.05)$. The strength of transversus abdominis muscle increased more in the training group. 4) The strength of transersus abdominis muscle had influence on the back pain during pregnancy: by improving lumbar stability the back pain decreased.
\end{abstract}

Keywords: transversus abdominis muscle, back pain, pregnancy, physiotherapy.

Gauta 2010 m. kovo 15 d.

Received on March 15, 2010

Priimta 2010 m. gegužès 31 d.

Accepted on May 31, 2010
Brigita Zachovajevienè

Kauno medicinos universitetas

(Kaunas University of Medicine)

Jankaus g. 2, LT-44221 Kaunas

Lietuva (Lithuania)

Tel +37069875901

E-mail brigitaz@medi.lt 